\title{
Urgency of Learning Language According to the Qur'an and Hadith in the Disruptive Era
}

\author{
Ikhwan Nur Rois ${ }^{1}$, Rubini $^{2}$ \\ \{roisnur04@gmail.com ${ }^{1}$, rubinihr80@gmail.com ${ }^{2}$ \} \\ Sekolah Tinggi Agama Islam Masjid Syuhada, Indonesia ${ }^{1,2}$
}

\begin{abstract}
Sophisticated technology that developed in the Disruptive 4.0 era is increasingly apparent in the field of education. The entry of the Disruptive era is a challenge to the world of education, more specifically, linguistics. The challenges that occur in the form of many people or students who are reluctant to learn the language of the Qur'an and Hadith. AlQur'an and Hadith are guidelines or the main foundation of all laws, sharia for humans, these two guidelines explain in detail all related to humans, both monotheism, stories, rules, commands and prohibitions, including explaining the importance of learning language, which includes the language of the Qur'an and Hadith itself, namely Arabic, as well as other languages. This paper will describe the importance of language learning (the language in question is Arabic) according to the Qur'an and the Hadith in the disruptive era. This type of research in this paper is a literature study or library research, with a descriptive approach. The data collection method used is the documentation method. The primary data in this paper is the Qur'an and Hadith, and supported by other literature relating to the discussion. The results of the study are that the urgency of language learning according to the Qur'an and the Hadith, the language in question is Arabic, namely: because Arabic is God's Revelation, because language as a communication tool can explore the Qur'an and Hadith, because Arabic it was prescribed by Rasulullah (peace be upon him) to study, Arabic as the official language of the world, and Arabic as a means of understanding other Islamic religious sciences.
\end{abstract}

Keywords: Urgency, Learning, Language, Disruptive Era

\section{Introduction}

The definition of language according to some linguists, including Dardjowidjojo [1] states that language is an arbitrary verbal symbol system used by members of a language community to communicate and interact with each other, based on the culture they share. Keraf [2] said that language is a social communication tool in the form of a sound-symbol system that results from human speech. A language is a tool for interacting with others and as a tool for thinking. Language is closely related to culture considering language is closely related to the mindset of a society. That is, language plays a very important role in the process of thinking and creativity. Language is symbolic, meaning that a word can symbolize any meaning [3]. Kridalaksana [4] said that language is an arbitrary symbol system used by a community to work together, interact, and identify themselves.

Based on some of the theories above, it can be concluded that language has a meaning as a symbolic social communication tool so that every human being can use different languages in certain societal environments. 
The language itself has several properties in it, such as a) Systematic, (b) Which likes, as explained by Santoso [5] called which languages like are language elements chosen randomly without basis. There is no logical connection between sound and the meaning symbolized, (c) Speech, (d) Human, (e) Communicative.

In general, language has a function as a communication tool both verbally and in writing. With language we can establish communication between fellow humans, even we can find out the meaning or purpose of language from our object's speech. Among the functions of language as other communication tools, such as (a) information function, (b) self-expression function, (c) adaptation and integration function, and (d) social control function [5]. Meanwhile, according to Halliday [6] the function of language as a communication tool is (a) Instrumental Functions, (b) Regulatory Functions, (c) Interactional Functions, (d) Personal Functions, (e) Heuristic Functions, (f) Imaginative Functions, (g) Representational Functions.

Learning is the process of interaction of students with educators and learning resources in a learning environment both formal and non-formal educational environments [7]. This means that language learning is an activity carried out by educators and students in a language learning environment by utilizing relevant learning resources and referring to the applicable curriculum. Whereas the purpose of language learning, according to Basiran [8] is communication skills in various communication contexts. The ability that is developed is the comprehension of meaning, role, interpretation, valuing, and expressing oneself through language.

The author's intent in this article, to explain language learning according to the Qur'an and the hadith is learning Arabic. Next, we will explain that the importance of learning Arabic according to the primary sources we used in this study.

The disruptive era has a huge impact on various fields, a very visible impact is the increasingly sophisticated technology, especially in digital devices, which we can now feel alldigital. And with this digital tool people can easily get it, and are free to use it. To use this digital tool, mastery of various languages is needed, this shows that the importance of language in facing the development of the current era. With language able to obtain various kinds of information, various kinds of knowledge that we need in a disruptive era like this, where we can get everything even without limits so that we can balance in life. In this article the author will discuss the urgency or importance of language learning according to the Qur'an and the hadith in the disruptive era.

Nowadays language has experienced significant developments, both in terms of rules, writing, media, and so on. Along with the rapid development of the times at this time, more and more languages are used in this world, including English, Arabic, Mandarin, German, and various languages in various countries respectively. This is quite felt by the people who care and pay attention to language and learning, but in the current disruptive era there are still many who do not pay attention to language when they use it.

Various languages exist in the world, there is one language that is no less important to maintain and preserve, namely the language contained in the Qur'an and hadith. The language by the wider community considers it not important, some say it is very difficult to learn this language. Yet for Muslims in particular, this language is very important to learn and even must master it, because with that language can understand what is contained in the Qur'an and also the hadith, which is a way of life for Muslims. Based on the above, the author is interested in discussing the importance of language learning (Arabic) according to the Qur'an and hadith to be learned in this disruptive era. 


\section{Methodology}

\subsection{Research Design}

In this study, we used a qualitative research design through a descriptive approach and literature review. As for what we describe in this article has a qualitative design including general, flexible and can develop and appear in the research process [9]. According to Sukmadinata [10] qualitative research is a study aimed at describing and analyzing phenomena, events, social activities, attitudes, beliefs, perceptions of individual and group thoughts. And according to Sugiyono [9] qualitative research is research that is based on the philosophy of post positivism, used to examine natural conditions of objects, (as opposed to being an experiment) in which researchers are as key instruments, sampling the source data is done purposively and snowball, data collection techniques with triangulation (combined), data analysis is inductive/qualitative, and qualitative research results emphasize the meaning rather than generalization.

Our research approach uses a descriptive approach with a literature review. Sugiyono [11] states that the descriptive method is a method used to describe or analyze a research result but is not used to make broader conclusions. Nazir [12] descriptive method is a method in examining the status of a group of people, an object, a set of conditions, a system of thought or a class of events in the present. The purpose of this descriptive study is to make a systematic, factual and accurate description, description, or painting of the facts, properties, and relationships between the phenomena investigated. While the literature review is research that makes the focus of the literature on books, journals, articles, or internet sources that help strengthen what is related to the theme of our article.

\subsection{Data Source}

According to Arikunto [13], Data sources are subjects from which the data can be obtained. In this article, the author uses two data sources, namely: primary data and secondary data. Primary data source, Suryabrata [14] is data that is directly collected by the author from his first source. While secondary data sources, namely data directly collected by researchers as support from the first source. It can also be said that the data is arranged in the form of documents. Primary data in this article are al Qur'an and hadith. Whereas the secondary data are books, journals that discuss language.

\subsection{Procedure of the Research}

Also, in collecting data through library research or library research, according to Ratna [15], literature study has three different meanings, including: (1) All reading material that may have been read and analyzed, both those that have been published or as a private collection. (2) Often associated with a theoretical framework or theoretical basis, i.e., theories used to analyze research objects. (3) Reading materials specifically related to the research object being studied.

According to Pohan [16] this literature review aims to collect scientific data and information, in the form of theories, methods, or approaches that have developed and have been documented in the form of books, journals, texts, notes, historical records, documents, etc. contained in the library. In this article, data gathering is done using the documentation method. 


\subsection{Data Analysis Techniques}

In the qualitative research, the technical stage of analyzing this data is a very difficult part for researchers because there are no well-formulated analytical methods that are explained by Miles and Huberman [17]. On the other hand, Stainback and Stainback [18] states "There are no guidelines in qualitative research for determining to have much data and data analysis is necessary to support and assertion, conclusion, or theory". Which means: There are no guidelines in qualitative research to determine how much data and analysis is needed to support conclusions or theories. According to Aziz [19] data analysis in qualitative research is carried out continuously from the beginning to the end of the study; with inductive; and look for patterns, models, themes, and theories.

Moleong [20] data analysis technique is an effort made by working with data, organizing data, sorting it into manageable units, synthesizing it, searching and finding patterns. Discover what is important and what is learned and decide what is told to others.

In qualitative research, data analysis activities are not work done after all data has been collected, but rather throughout the research process, from planning, collecting data to interpreting or discussing field data. Data analysis activity is Ibrahim [7] researchers' efforts in compiling data to be more systematic, related to one another, so that it can provide a certain meaning, by the nature of the object being analyzed. The data analysis technique in this article is content analysis using 3 steps, namely editing, organizing and inference.

\section{Discussion}

\subsection{Language According to the Al-Qur'an and Hadith}

\subsubsection{Al-Qur'an}

Some verses from al-Qur'an which we describe related to the importance of language, including [21]:

a. Surah Az-Zukhruf: 03

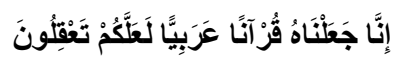

Meaning: "Indeed, we make the Qur'an in Arabic so that you understand it".

Based on the above verse, Tafsir Al-Mukhtashar/Markaz Tafsir Riyadh, under the supervision of Shaykh Dr. Shalih bin Abdullah bin Humaid, explained the meaning contained therein: Namely Allah revealed it in Arabic because every prophet was given a book in the language of his people. And we made the Qur'an in Arabic so that you can understand it, Arabs, and understand its meaning and content because it uses very fluent language that explains the purpose of its contents and is easy to understand.

b. Surah Az-Zumar: 27-28

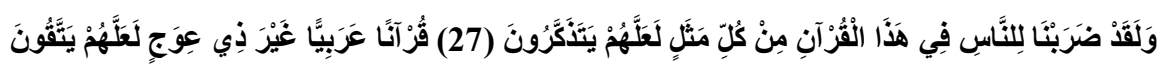


Meaning: "Indeed, We have made it for humans in this Qur'an every kind of parable so that they can learn (27). this is Al-Qur'an in Arabic which is not bent (in it) so that they fear this is AlQuran in Arabic that is not bent (in it) so that they fear".

Based on the above verse, Tafsir Al-Mukhtashar/Markaz Tafsir Riyadh, under the supervision of Shaykh Dr. Shalih bin Abdullah bin Humaid, explained the meaning contained therein: Namely with all the parables they need for their religious affairs. So, that you take lessons. Al Quran in Arabic Namely with Arabic that is clear and does not contain disputes and disagreements, and doubts in it. Another opinion says that there cannot be any language error.

c. Surah Asy-Syu'ara: 192-195

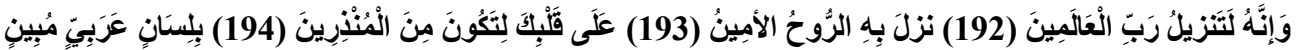

Meaning: “And this Qur'an was sent down by the Lord of hosts (192), he was brought down by Ar-Ruhul Amin (Gabriel) (193), into your heart (Muhammad) so that you become one of those who gives a warning (194), with clear Arabic (195)".

Based on the above verse, Tafsir Al-Mukhtashar/Markaz Tafsir Riyadh, under the supervision of Shaykh Dr. Shalih bin Abdullah bin Humaid, explained the meaning contained therein: Allah made the Koran use Arabic in accordance with the language of the Apostle who is an Arabic so that the polytheists do not say "we cannot understand what you say other than our language" so that the Arabic-language Qur'an can cut off their reasons and refute their claims.

d. Surah Ar-Ra'du: 37

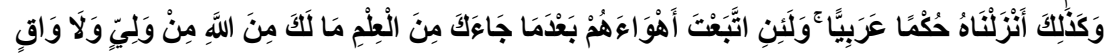

Meaning: "And thus, We have sent down the Qur'an as a (correct) rule in Arabic. And if you follow their passions after knowledge comes to you, then there will be no protector and guardian for you against Allah".

Based on the above verse, Tafsir Al-Mukhtashar/Markaz Tafsir Riyadh, under the supervision of Shaykh Dr. Shalih bin Abdullah bin Humaid, explained the meaning contained in it: We sent down the Qur'an containing the principles and details of the Sharia in Arabic, as We revealed the other books to the Apostles in their language. So, they hope that you follow it. What God taught you. Allah Who arranges your affairs and helps you. And protect you from His punishment.

e. Surah An-Nahl: 103

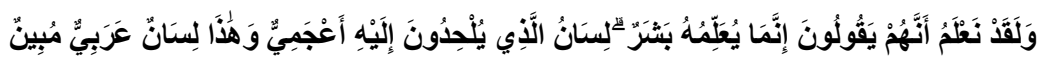


Meaning: "And verily We know what they say: "Verily the Koran was taught by a man to him (Muhammad)". Even though the language of the person they accused (Muhammad) learned of him was the language 'Ajam, while the Koran was in bright Arabic".

Based on the above verse, Tafsir Al-Mukhtashar/Markaz Tafsir Riyadh, under the supervision of Shaykh Dr. Shalih bin Abdullah bin Humaid, explained the meaning contained in it: Namely We know that the infidels said: "Actually the person who taught Muhammad alQur'an is a human being and not an angel". According to their confession, the slave belonged to Fakih bin Mughirah, named Jabar, who was a Christian then converted to Islam. The language of the people they consider to be the people who taught you the Qur'an is a language which has no fluency. Al-Qur'an which has high eloquence and clear explanation. you say that those who teach it are from the 'ajam', whereas you are not able to compete with any of the letters in the Qur'an, even though you are eloquent experts and kings in the knowledge of balaghah; how can you say this accusation?

f. Surah Asy-Syura: 07

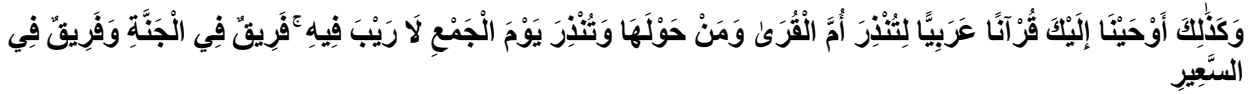

Meaning: "Thus we reveal to you the Koran in Arabic so that you give a warning to the ummul Qura (inhabitants of Mecca) and the inhabitants (countries) around him and give a warning (also) about the day of gathering (doomsday) that there is no doubt in him. A group enters heaven, and a group enters Jahannam".

Based on the above verse, Tafsir Al-Mukhtashar/Markaz Tafsir Riyadh, under the supervision of Shaykh Dr. Shalih bin Abdullah bin Humaid, explained the meaning contained therein: Namely in the language of your people, as We sent every apostle to the religion of his people, namely the city of Mecca. And what is meant is that the Prophet gave a warning to the inhabitants of the city of Mecca that you warn them of the doomsday of doom. Because that day is the time for the gathering of creatures and the gathering of spirits and their bodies. Ie without any doubt, they will all gather in the mahsyar fields and then part with each other according to the place specified for them.

g. Surah Al-Ahqaf: 12

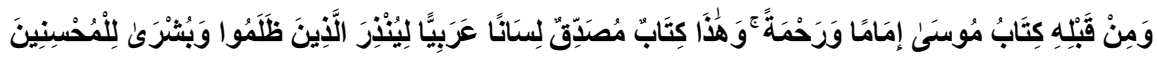

Meaning: "And before the Koran there was the book of Moses as guidance and mercy. And this (Al Quran) is a book that justifies it in Arabic to give warnings to people who do wrong and give good news to those who do good".

Based on the above verse, Tafsir Al-Mukhtashar/Markaz Tafsir Riyadh, under the supervision of Shaykh Dr. Shalih bin Abdullah bin Humaid, explained the meaning contained therein: namely the book of Moses, the Torah that precedes the Qur'an. These two books are by following the principles of the Sharia, this shows that the Qur'an is true and comes from Allah Who guides in religion, and it is God's mercy for those who believe in it. The Koran is the book that justifies it, is to justify the book of Moses which is guidance and mercy, and also justifies 
the other books of God and uses the Arabic language they understand. To warn (you) of the punishment of Allah, so there is no reason for them. And their end is victory and heaven in return for their kindness.

\subsubsection{Hadith}

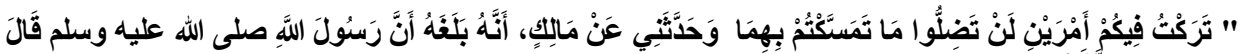

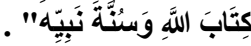

Meaning: From Malik, he had told him that the Prophet Muhammad said: "I leave something with you, if you hold fast to him, you will not be lost forever, namely the Book of Allah and my Sunnah" (HR. Imam Malik).

\subsubsection{Sayings of the Companions of the Prophet Muhammad}

a. Imam Asy-Syafi'i rahimahullah said,

$$
\text { فعلى كل مسلم أن يتعلم من لسان العرب ما بلفه جهده حتى يشهل به أن لا إله إلا الله وأن محمد عبده ورسوله }
$$

Meaning: "It is compulsory for every Muslim must learn Arabic as hard as he can. So, he testifies that there is no worship worthy of worship except Allah Ta'ala and Muhammad are His servants and messengers, and with him, he can read the book of Allah...”.

b. Shaykh Islam Ibnu Taimiyah rahimahullah said,

$$
\text { اللِّسََانُ العَرَبِي شِعَارُ الإسنلاِمِ وَأَهْبِهِ }
$$

Meaning: "Arabic is the sign of Islam and the sign of Muslims. "It is mentioned in the Iqtidha" Shirath Al-Mustaqim".

c. Ibn Kathir when explaining the second verse of Joseph's letter states,

$$
\text { لأن لغة العرب أفصح اللغات وأبينها وأوسعها، وأكثرها تأدية للمعاني التي تقوم بالنفوس }
$$

Meaning: "Because Arabic is the most fluent, clearest, most extensive (vocabulary) language, and contains the most soul-calming meanings".

d. Ibn Kathir rahimahullah said,

$$
\begin{aligned}
& \text { فلهذا أنزلَ أشرف الكتب بأثرف اللغات، على أشرف الرسل، بسفارة أشرف الملائكة، وكان ذلك في أشرف بقاع ألثرف }
\end{aligned}
$$

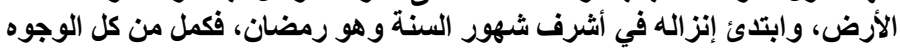

Meaning: "Because the Qur'an is the noblest book, sent down with the noblest language, taught to the noblest Apostles, delivered by the noblest angels, sent down in the noblest places on earth, also sent down on the glorious moon that is Ramadhan month. From various sides, we can judge how noble the Holy Qur'an”. 
Based on the primary reference sources, namely the Al-Qur'an and Hadith and strengthened by the words of the Companions of the Prophet Muhammad, we can conclude that Arabic is an important scientific discipline to be studied for every Muslim.

\subsection{The Urgency of Learning Arabic According to Qur'an and Hadith}

The author has explained above about the arguments or verses that explain the importance of language learning according to the Qur'an and the hadith, at this most important point, the writer explains the very importance (urgent) of Arabic itself for Muslims to learn, including:

\subsubsection{Because Arabic is God's Revelation}

Al-Qur'an is a miracle of God, a miracle is a revelation that Allah sent to the Prophet Muhammad, where Allah revealed the Qur'an in Arabic, therefore Arabic is also a revelation of God revealed to the Prophet Muhammad. This is evidenced in the word of God in Surah AsyShura: 07, which means: "Thus We reveal to you the Koran in Arabic, so that you give warning to the ummul Qura (inhabitants of Mecca) and residents (countries) around him and give warnings (also) about the day of gathering (doomsday) which there is no doubt in him. A group enters heaven, and a group enters Jahannam".

\subsubsection{Because Language as a Communication Tool Can Explore the Qur'an and the Hadith}

Al-Qur'an and Hadith are sources of guidance on human life and both use Arabic, therefore Arabic acts as a communication to explore both human guidelines, in harmony with the word of God in Surah Az-Zukhruf: 03, which means: "Indeed, we make the Qur'an in Arabic so that you understand it".

\subsubsection{Because Arabic is Prescribed by the Prophet Muhammad to be Studied}

Every Sharia or teachings that the Prophet Muhammad left his followers must be implemented and obeyed. Related to that, the Arabic language becomes urgent or prescribed by the Prophet Muhammad to study. This is by following the hadith of the Prophet Muhammad, which means: "I leave something with you, if you hold on to it, you will not be lost forever, that is, the Book of Allah and my Sunnah".

\subsubsection{Because Arabic is the Official Language of the World}

Released by the United Nations or what we know as the United Nations. The UN currently has six official languages, namely English, Arabic, Chinese, French, Russian, and Spanish which are used in intergovernmental meetings, and making documents Arabic is used as the official language of countries in 26 countries in the world. Arabic was declared as the official language of the world by UNESCO UN on December 18, 1973 as World Arabic Day, with the establishment of UNESCO, learning Arabic became something urgent in the world of international education. 


\subsubsection{Because Arabic is a Tool for Understanding other Islamic Religious Sciences}

Among the religious sciences, such as: Jurisprudence, Aqedah, Morals, Tafsir, Tawhid, and others. It all certainly uses one source, which source uses Arabic, therefore one of the Arabic languages becomes urgent to learn and understand for people who want to understand the other religious sciences. As Umar Bin Khattab said, learn Arabic because this language is part of your religion.

\section{Conclusion}

From the description above, it can be concluded that the language referred to in this article in Arabic. This type of research is a literature review, with data sources from the Qur'an and Hadith, the data collection method is documentation and analysis of data content analysis with three steps of editing, organizing, and inference. The urgency of language learning (Arabic) according to the Qur'an and the hadith is: because Arabic is a revelation from God, because Arabic is a communication tool in order to explore the Qur'an and Hadith, because Arabic is prescribed by the Prophet Muhammad SAW to learn, Arabic as the official language of the world, and Arabic as a means of understanding other Islamic religious sciences.

\section{Acknowledgments}

The author would like to thank Ramya Rachmawati, S.Sc., M.Sc., Ph.D. for guiding and correcting our article, and also thanks dr. Violeta, Sp.OG, which has subsidized some of our research costs, so that it can be resolved properly and smoothly.

\section{References}

[1] G. Keraf, "Composition: An Introduction to Language Proficiency.” Flores: Nusa Indah, 2004.

[2] U. Khair, "Pembelajaran Bahasa Indonesia dan Sastra (BASASTRA) di SD dan MI," AR-RIAYAH J. Pendidik. Dasar, vol. 2, no. 1, p. 81, 2018.

[3] B. Sagendra, Belajar dan Pembelajaran Bahasa Indonesia. Semarang: Linggayoni Publishing, 2014.

[4] H. Kridalaksana, Kamus Linguistik (edisi keempat). Gramedia Pustaka Utama, 2013.

[5] K. B. Santoso, Problematika bahasa Indonesia: sebuah analisis praktis bahasa baku. Rineka Cipta, 1990.

[6] M. A. K. Halliday, Language as social semiotic: The social interpretation of language and meaning. Hodder Education, 1978.

[7] M. A. Ibrahim, "Metodologi penelitian kualitatif," Bandung Alf., 2015.

[8] M. Basiran, "Apakah yang Dituntut GBPP Bahasa Indonesia Kurikulum 1994," Yogyakarta: Depdikbud, 1999.

[9] S. Sugiyono, "Research Method Quantitative and Qualitative R\&D," Alf. Bandung, 2010.

[10] N. Syaodih Sukmadinata, "Metode Penelitian Pendidikan," Bandung: Rosda, 2007.

[11] S. Sugiyono, "Educational Research Methods: Quantitative, Qualitative, and R \& D Approaches," Bandung CV. Alf., 2010.

[12] M. Nazir, "Metode Penelitian," Jakarta Ghalia Indones., 1988.

[13] S. Arikunto, "Research procedure a practical approach," Jakarta PT Rineka Reserv., 2010.

[14] S. Suryabrata, "Metodologi Penelitian.” Rajawali Pers, Jakarta, 2006. 
[15] N. K. Ratna, "Penelitian Sastra: Teori, Metode, dan Teknik," Yogyakarta: Pustaka Pelajar, 2004.

[16] R. Pohan, “Metodologi Penelitian Pendidikan,” Yogyakarta, Lanarka, 2007.

[17] M. B. Miles and A. M. Huberman, "Analisis data kualitatif." Jakarta: UI press, 1992.

[18] S. Stainback and W. Stainback, Understanding \& Conducting Qualitative Research. ERIC, 1988.

[19] M. T. Aziz, “Asal Usul Bahasa dalam Perspektif Al-Qur'an dan Sains Modern,” utile J. Kependidikan, vol. 2, no. 2, pp. 125-131, 2016.

[20] J. Moleong Lexy, "Qualitative Research Methodology.” Bandung: PT Adolescent Rosdakarya Offset, 2007.

[21] Balitbang Departemen Pendidikan Nasional, Implementasi Kurikulum Berbasis Kompetensi. Jakarta, 2002. 